\title{
The ecological outcomes of collaborative governance in large river basins: Who is in the room and does it matter?
}

Keywords: collaborative governance; ecological outcomes; social-ecological systems; river basin management; sustainable water management

\begin{abstract}
Although collaborative governance has been presented as central in environmental management, it does not guarantee sustainable natural resource management. Due to methodological challenges and a lack of robust interdisciplinary data, few studies have linked collaborative processes to ecological outcomes. This paper contributes to that research effort by investigating whether the relative involvement of different interest groups in deliberations matters from an ecological perspective. To that end, this interdisciplinary paper links social and ecological indicators across two large French river basins in a dataset spanning 25 years. We find that the presence of different interest groups - agricultural, industrial and NGOs during deliberations is linked to different ecological outcomes. Most notably, the composition of present members does not play the same role depending on the type of pollution source studied (e.g. point- and diffuse sources).
\end{abstract}

\section{Introduction}

Collaborative governance has become common practice in environmental management, notably for river basin management. Yet, research is still needed to understand "if, when, and how collaboration is effective" to reach desirable ecological outcomes (Bodin 2017, p.1). The existing research on the environmental effectiveness of collaborative governance has mostly studied regulatory outputs rather than ecological outcomes (Koontz and Thomas 2006). The few articles that have linked collaborative governance to ecological conditions in the context of river basin governance sketch a potentially positive but complex relationship (Newig and Fritsch, 2009; Biddle and Koontz, 2014; Scott, 2015; Scott, 2016; Biddle, 2017).

None of these studies looked at power dynamics - a key element for successful collaborative processes (Purdy 2012). Our work, therefore, endeavours to contribute to existing evidence through studying the relative involvement of strategic interest groups in committee discussions. We believe that the following question is worth asking: For a chosen Social-Ecological System (SES), how does the relative involvement of different interest groups within collaborative governance institutions influence the system's ecological state?

To answer that question, we collated several decades' worth of longitudinal data on meeting minutes and the ecological state of rivers within two French river basins. Understanding if and how the attendance of different interest groups translates into different ecological outcomes helps outline the terms and conditions of effective collaborative governance for improving ecological conditions (Jager et al. 2020; Bodin 2017). Our research develops an interdisciplinary approach to analyse ecological indicators (water quality 
parameters in this case) within the field of collaborative governance. It does so at the system level, within a SES-approach fit to the study of large river basins (Ostrom, 2009). The statistical modelling approach developed in this paper can open new methodological perspectives to the existing literature on the implementation of the European Union (EU) Water Framework Directive (WFD), dominated by descriptive and qualitative approaches (Boeuf and Fritsch, 2016).

\subsection{The ecological effectiveness of collaborative governance}

Collaborative governance is now instilled in water management - notably in EU countries through the implementation of the WFD (e.g. Cashman and Lewis 2007; Jager et al. 2016; Graversgaard et al. 2017). Collaborative governance is "a governing arrangement where one or more public agencies directly engage non-state stakeholders in a collective decisionmaking process that is formal, consensus-oriented and deliberative and that aims to make or implement public policy or manage public programs or assets" (Ansell and Gash, 2008, p. 544). The involvement of stakeholders in decision processes has been recommended for the management of SESs like freshwater systems (Ostrom 1990), to deal with potential conflicts (Harley, Metcalf, and Irwin 2014), and gather information over complex multi-actor issues (Heikkila 2017). In the case of the EU WFD, stakeholder participation is presented as "not an end in itself but a tool to achieve the environmental objectives" (European Commission and Directorate-General for the Environment 2003, p.6).

Collaborative processes are not the only potential drivers of ecological changes, however. Sector specific regulation - e.g. changes in the Common Agricultural Policy in the EU for water - might also play an important role. But command and control regulations - although they can be efficient in specific socio-economic contexts (Dalgaard et al. 2014) - have shown their limitation, notably when it comes to implementation (Tingey-Holyoak 2014). Stakeholder participation in collaborative governance processes - such as deliberations - is theorised to yield positive ecological outcomes through two mechanisms. First, it can improve regulatory outputs as more comprehensive information is made available by different actors. And secondly, it facilitates the implementation of those decisions (Newig et al. 2018).

Nonetheless, collaboration in itself does not always lead to ecological or social improvements. When it comes to SES management, there is no such panacea (Ostrom 2007). Collaboration attempts can also cause conflicts and the reproduction of status quo, due to power dynamics (Phillips, Lawrence, and Hardy 2002; Behagel and Arts 2014; Bodin 2017). Specifically, power is linked to the ability of stakeholders to attend deliberations, where the meaning itself of the ecological problem at hand gets negotiated (Harley, Metcalf, and Irwin 2014). The relative representation of different interest groups in deliberations entails risks of exclusion and domination (Purdy 2012). Indeed, "who the participants are and who they represent are of signal importance to collaboration" (Emerson, Nabatchi, and Balogh 2012, p.11). Henceforth, participating in deliberations can allow an interest group to influence regulatory outputs and - through that - the condition of ecosystems. 


\subsection{River basin management}

Water resources are common-pool resources, meaning they are non-excludable but rivalrous and, therefore, potentially subject to overuse and negative externalities (e.g. pollution), leading to resource depletion (Ostrom 1990). River basins (or watersheds) play a key role in the cycling of water resources, transporting freshwater between landscape sources and sinks, whilst draining all hydrologically-connected land in the process. However, river basins can be vast and do not only include water and ecological elements, but also social elements, such as groups of actors and institutions. In that sense, river basins are SESs (PahlWostl 2006; Ostrom 2009). Actors of a shared water system, such as a large river basin, often have little in common except for their interdependence to the same vital resource. Overuse and conflicts are frequent as each actor has a different understanding of what correct water management means (Baudoin and Arenas 2020). As modern economies expand and populations increase, unprecedented pressures on rivers are seen. Conflicts are likely to become more prevalent with climate change (Bates et al., 2008). To sustainably manage river basins, a systems perspective has been proposed (Voulvoulis et al., 2017), i.e. the creation of governance institutions with a holistic approach at the geographical scale of river basins.

River basin management brings challenges of water quality and quantity, hydrogeomorphology and biology, to name a few, and these topics are inextricably linked. We focus in this paper, however, on water quality, a crucial set of parameters underpinning good ecological condition and ecosystem function, and a central issue in the river basins studied (Kristensen, Whalley, and Klančnik 2018). Managing water quality englobes both point and diffuse sources of pollutants. These sources of pollution require different regulatory approaches (Graversgaard et al. 2018). Diffuse pollution sources are more complex to identify (as they are considered a 'micro point-source'; Harrison et al., 2019), monitor and resolve (Haycock and Muscutt 1995; O'Shea 2002). Diffuse Water Pollution from Agriculture (DWPA) has been a specific focus of research efforts, as agricultural activities are seen to be a primary cause of nutrient pollution worldwide, notably nitrogen and phosphorus (Harrison et al. 2019).

\subsection{An interdisciplinary approach to include ecological outcomes}

Our paper tackles the lack of research on ecological outcomes in the context of the collaborative governance of natural resources (Ansell and Gash, 2008; Newig and Fritsch, 2009). Indeed, the study of ecological parameters as dependent variables remains marginal. Previous research in collaborative governance has studied the outputs of governance more than the outcomes (Koontz and Thomas 2006; Thomas and Koontz 2011). These studies points to a positive effect of participation on the environmental standard of outputs (Reed 2008; Kochskämper et al. 2016; Jager et al. 2020). Nonetheless, there is a nuance between the influence of the involvement of interest groups on the environmental standards of regulatory outputs and their effect on reaching ecological goals (Rimmert et al. 2020). Further, there is an inherent uncertainty around the ecological effect of regulatory outputs, due to the complexity and unpredictability of ecosystem dynamics (Rice 2013; Jarvie et al. 2013). 
Linking collaborative governance processes to ecological outcomes, statistically, is a

124

125

126

127

128

129

130

131

132

133

134

135

136

137

138

139

140

141

142

143

144

145

146

147

148

149

150

151

152

153

154

difficult endeavour. First of all, tracking quantitatively collaborative processes presents many challenges, including the data collection, particularly over longer time frames (Ulibarri and Scott 2017; Emerson and Nabatchi 2015). Further, this lack of research can be explained by the inherent struggles of interdisciplinary research (Leahey, Beckman, and Stanko 2017), as it requires integrating approaches from social and natural sciences. Assessing ecological improvements is preferably done over a long timeframe and at the system-scale. Collecting time-series data to link collaborative processes to ecological outcomes is particularly challenging (Thomas and Koontz 2011) and as a result, only a few studies have evaluated the ecological outcomes of collaborative river basin governance (Jager et al. 2020).

Scott (2015) found a positive link between the existence of a river basin group with responsibility on biodiversity and water and quality good ecological indicators. Biddle \& Koontz (2014) found an encouraging positive relationship between sustained participation and the attainment of goals. Biddle (2017) and Scott (2016) emphasized the importance of financial capacity. Finally, results differed depending on the ecological indicator selected as dependent variable (Scott 2015), highlighting the complexity and multi-dimensionality underlying ecological outcomes (Agrawal and Chhatre, 2011).

\subsection{Presentation of the empirical context}

The French river basin institutions, instaured by the 1964 French Water Law, have driven a form of collaborative river basin governance long before the 2000 EU WFD. Each French river basin has a public Water Agency (Agence de l'Eau), and a basin committee (comité de bassin), also called "water parliament". This governance body is central to a broader multilevel and multi-actor national system (Barataud, Durpoix, and Mignolet 2014). As shown in figure 1 , the role of these committees is not purely consultative. In plenary sessions, basin committee members deliberate to draft and vote River Basin Management Plans (RMBPs), and validate Water Agency multi-year programs of measures. Among other things, basin committee members have a say on the way water taxes are designed and reinvested for infrastructure developments. Therefore, we can expect to see an impact of the participation patterns of committee members, through time, on deliberations, on voted regulatory outputs, and then potentially on the ecological conditions of the basins they supervise.

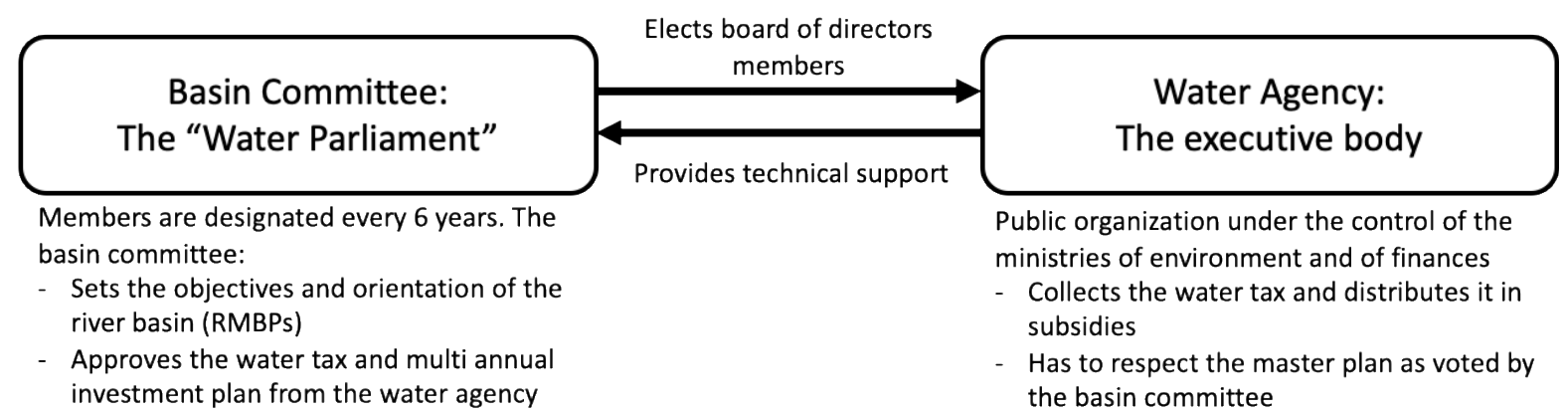

Figure 1. Simplified schematic demonstrating the functioning of French river basin institutions. 
The composition of river basin committees is set by law, to include state representatives ( $20 \%$ of committee), water users ( $40 \%$; including economic and non-economic actors) and local authorities (40\%). The exact composition of the committees has evolved through the years via successive regulatory changes. The rules of designation of members vary depending on their representative role. For example, the agricultural representatives are elected by regional agricultural councils, while NGO representatives are proposed by their corresponding national federations. Memberships are then validated by the state representative in charge of the river basin (préfet de bassin).

In French river basins, basin committee members have been taking part in deliberations only if they attend the meetings. Attendance has been a concern in river basin committees, as meetings require time and technical expertise. Members are not paid to participate, but are compensated for their travel expenses. A decree was published in 2014 to try to rein in absenteeism. In case of absence, a member can give their voting right to another member. A present member can receive the voting right of maximum two other members.

\subsection{Development of a research model}

In previous studies, attendance has been considered an important manifestation of stakeholder involvement (Scott, Ulibarri, and Scott 2018). Indeed, face-to-face dialogues are necessary, although not sufficient alone, for collaborative processes to take place (Ansell and Gash 2008). To attend deliberatory meetings, stakeholders need first of all to be interested in participating and to have the resource to come and speak up. In inter-organisational dynamics, three important sources of power have been identified - namely, authority, resources and discursive legitimacy (Hardy and Phillips 1998). The relative presence of different interest groups in meetings can therefore be a proxy of their respective source of power regarding the deliberative process. In the case of basin committee members, the ratio of presence in meetings among interest groups indicates their authority - granted to them by the number of members sitting that they have - and their resource, e.g. the time and expertise to participate in deliberations.

Assessing collaborative processes and power dynamics is an analytical challenge, especially in the long-term (Purdy 2012; Emerson and Nabatchi 2015; Ulibarri and Scott 2017). But a longitudinal approach is important when considering long processes of deliberation, the implementation of outputs, and the reaction of the ecosystems to those actions. Covering a greater time frame allows for the evolution of power dynamics to be observed (Ran and Qi 2018). Considering these challenges, tracking the attendance to meeting minutes offers temporal stability and allows to grasp important aspects of the source of power of different groups in collaborative processes, although it does not allow to assess how they use this power in deliberations (Purdy, 2012).

As it is, "little theory exists to guide conveners, participants, and researchers in understanding how power shapes collaborative processes and outcomes" (Purdy 2012, 197 p.410). The relative presence of interest groups can affect regulatory outputs and through 198 that have ecological consequences. Our paper focuses on these ecological outcomes. As 
aforementioned, participation is expected to lead to better ecological conditions through the drafting of better decisions and the better implementation of these decisions (Newig et al. 2018; Jager et al. 2020). In this case, interest groups develop a shared understanding of the environmental issues and engage in social learning (Pahl-Wostl, 2006; Ansari et al., 2013; Fan and Zietsma, 2017). Ideally, the increased involvement of different groups will lead to improvements regarding the ecological impact of their respective activities. Nonetheless, another potential prediction could be that the collaboration processes reinforce pre-existing power asymmetries, with the cooptation of environmental issues by economic interests (Selznick, 1949; Behagel and Arts, 2014). In that second case, the increased involvement of actors would lead to the stagnation or worsening of the ecological impact of their respective activities. Due to the methodological challenges mentioned above, our paper does not measure whether the collaborative processes taking place in basin committees lead to shared understanding or to power struggles. We therefore focus our research effort on the relationship between the relative presence of different interest groups and different ecological outcomes:

$\mathrm{H} 1$ : The relative presence of different interest groups in collaborative governance processes will be linked to different ecological outcomes.

Further, the notion of quality of a decision on ecological topics needs to be taken with caution when we consider the relative uncertainty and unpredictability of their outcomes in ecosystems (e.g. Rice, 2013), the difficulty to assess those outcomes (e.g. Morandi et al., 2014), and the multi-dimensionality of those outcomes (Agrawal and Chhatre, 2011). This leads us to our second hypothesis:

$\mathrm{H} 2$ : The impact of the presence of different interest groups on ecological outcomes will be different depending on the ecologically relevant indicator chosen as dependent

The overall research model we developed can be seen in Figure 2 here below.

\begin{tabular}{|c|}
\hline $\begin{array}{l}\text { Participation share by group (basin,year) } \\
\text { 1. Industry } \\
\text { 2. Agriculture } \\
\text { 3. NGOs }\end{array}$ \\
\hline
\end{tabular}

Ecologically relevant water quality parameters (basin,year + lag)

1. 5-day Biochemical Oxygen Demand

2. Total Phosphorus

3. Nitrates

Controls

- River flow (basin,year + lag)

- Land use (basin,year +lag)

- Financial means of governance body (basin,year)

Figure 2. Layout of the research model, demonstrating the data used to represent institutional actors (participation share by group) and ecological outcomes (ecologically-relevant water quality parameters). The controls allow for standardization between river basins and over time. 


\section{Methodology}

\subsection{Data and measurements}

We collated a panel dataset going from 1990 to 2018 for two French river basins, Loire Bretagne (LB) and Seine-Normandie (SN). Basic geographic information regarding both river basins can be found in Table 1, and their geographical location in France is presented in Figure 3.

Table 1.

Geographic profile of studied river basins.

\begin{tabular}{|c|c|c|c|c|c|}
\hline & \multirow{2}{*}{$\begin{array}{l}\text { Population in millions } \\
\qquad(2018)\end{array}$} & \multirow{2}{*}{ Surface (km2) } & \multicolumn{3}{|c|}{ Land use mix (CLC 2018) } \\
\hline & & & Artificial & Agricultural & Forest and semi-natural \\
\hline SN & 19.0 & 94,000 & $7 \%$ & $70 \%$ & $22 \%$ \\
\hline LB & 13.3 & 155,000 & $5 \%$ & $74 \%$ & $20 \%$ \\
\hline
\end{tabular}

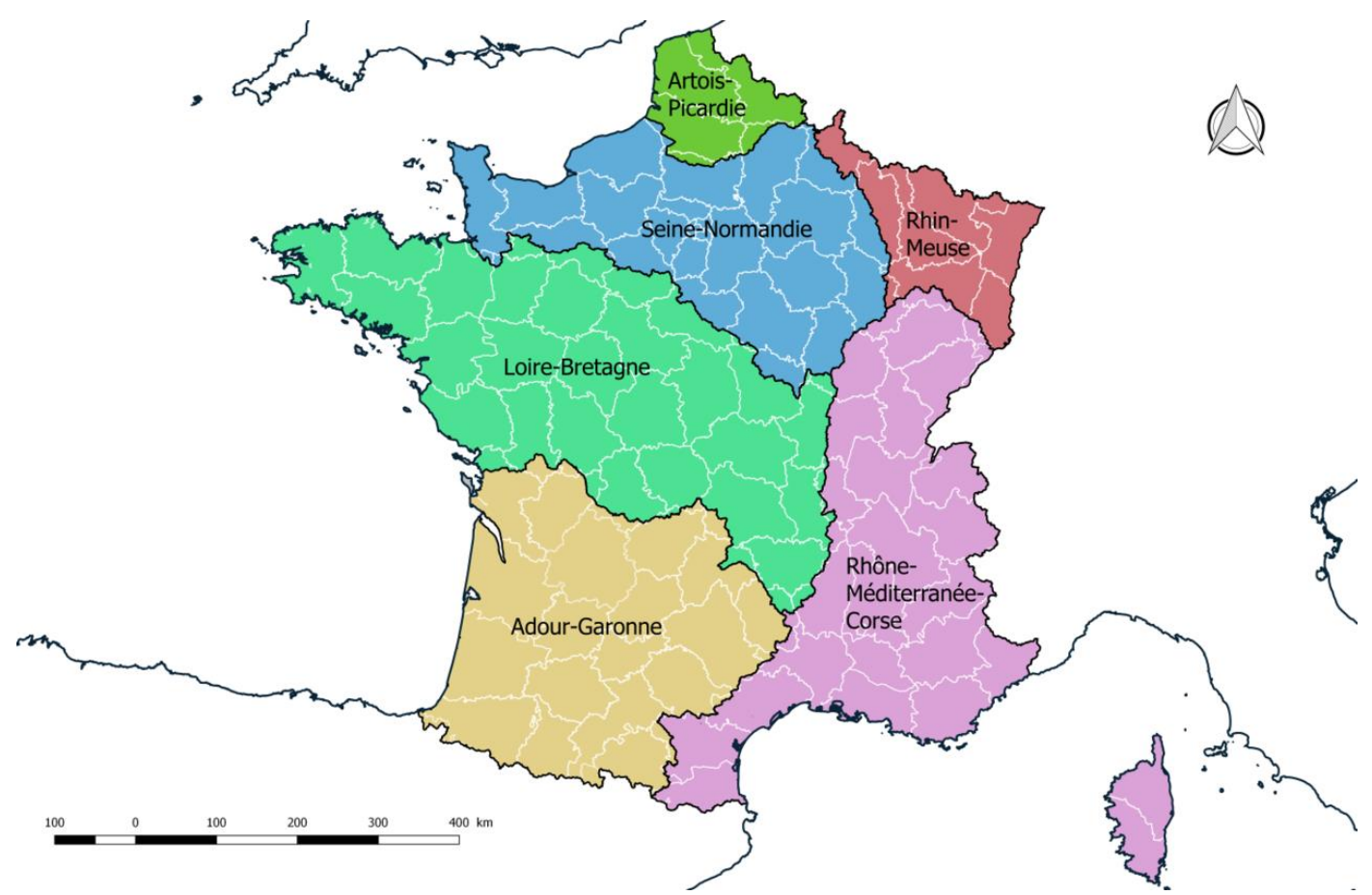

Figure 3. Map of French hydrographic basins, with LB in light green and SN in blue. Source: Wikicommons, Roland45, CC BYSA 4.0

\subsubsection{Dependent variables: The ecological state of river basins}

Water quality parameters are a key precondition for the ecological state of river ecosystems. Monitoring water quality is complex and expensive, and a multitude of sensing and analytical techniques (in-situ and ex-situ) have been developed over the years. Building our dataset, we considered several historical developments: through the years, the number of monitoring stations has increased, as well as the number of samples taken and the number of parameters sampled. Finally, technological advances have improved the limits of detection and the frequency of sampling for many common water quality parameters, allowing more 
stringent environmental standards to be set for compliance in addition to raising awareness of emerging pollutants.

As we pursue longitudinal research, our choice of dependent variables is limited to measures that have been monitored consistently since the beginning of the timeframe. In the basins studied, there is no systematic historical indicator tracked for the overall ecological state of the basin as metrics have been constantly updated with improving scientific knowledge and changing regulation. Therefore, the three water quality parameters chosen as indicators of ecological outcomes were: 5-day biochemical oxygen demand (BOD5), total phosphorus (TP) and nitrates $\left(\mathrm{NO}_{3}\right)$. These parameters drive the ecological health of river systems by influencing the rate at which key biological processes occur (e.g. metabolic processes, reproduction, respiration). Further, these parameters have been monitored in French rivers for decades, since the inception of the basin committees. This means that committee members have been aware of, or at least informed about them, allowing them to have developed a shared understanding of those aspects of river systems. A detailed description of the ecologically relevant parameters included in this study can be seen in Table 2.

Mean annual concentrations were not readily available for the three parameters at the level of the river basins. Therefore representative trends had to be computed. Individual measurements were collected through the French public database - Naïades. We only collated measurements made from stations included in the network "Réseau de Contrôle de Surveillance" (RCS); a network created to give a long-term overview of the river basin using representative stations from the entire database (Laronde and Petit, 2010). For the year 2016, those RCS stations represent $37 \%$ of available stations in the SN territory and $17 \%$ in the case of the LB territory. Many of those stations existed before 2007, when the RCS network was instituted, as this network aimed to build on existing infrastructure to maintain the historical continuity in monitoring efforts. For each RCS station, we took the annual $90^{\text {th }}$ percentile concentration of each parameter. We then took the mean of these $90^{\text {th }}$ percentile concentrations across the RCS stations at the basin level. Following that procedure, we obtained high Pearson correlation indices with the few examples of basin-level historical aggregations obtained from the $\mathrm{LB}$ river basin agency on $\mathrm{BOD} 5, \mathrm{NO}_{3}$ and $\mathrm{TP}$, supporting the validity of our methodology. Analyses run on the entire database without selecting stations produced similar historical trends but with higher uncertainty; again, validating our approach. For the year 2000, potentially erroneous BOD5 data at 11 (of total 134) sites in the SN basin were removed from the trend analysis. This did not significantly alter our trends or results but corrected the standard deviation anomaly for that year. 
Table 2. Characteristics of the ecologically relevant parameters included in our models.

\begin{tabular}{|c|c|c|c|}
\hline Parameter & Description & Source/driver & Relevant legislation \\
\hline $\begin{array}{l}\text { 5-day } \\
\text { Biochemical } \\
\text { Oxygen } \\
\text { Demand } \\
\text { (code } 1313 \text { in } \\
\text { the Naïades } \\
\text { database) }\end{array}$ & $\begin{array}{l}\text { Expressed as } \mathrm{mg} \mathrm{O}_{2} \mathrm{~L}^{-1} \text {. Represents } \\
\text { the quantity of oxygen required by } \\
\text { the microbial community to } \\
\text { metabolize the organic compounds } \\
\text { present in solution - linked to the } \\
\text { quantity of dissolved oxygen } \\
\text { available for higher-trophic } \\
\text { organisms. }\end{array}$ & $\begin{array}{l}\text { Commonly used as a surrogate for } \\
\text { the organic content of treated } \\
\text { wastewater (a metric of treatment } \\
\text { efficacy). Organics emitted to river } \\
\text { systems in wastewater effluent } \\
\text { > Typically point-source pollutant }\end{array}$ & $\begin{array}{l}\text { - EC Urban } \\
\text { Wastewater } \\
\text { treatment Directive } \\
\text { (91/271/EEC) } \\
\text { - } 1992 \text { French water } \\
\left.\text { law ( } n^{\circ} 92-3\right)\end{array}$ \\
\hline $\begin{array}{l}\text { Total } \\
\text { phosphorus } \\
\text { (code } 1350 \text { in } \\
\text { the Naïades } \\
\text { database) }\end{array}$ & $\begin{array}{l}\text { Expressed as mg } \mathrm{P} \mathrm{L}^{-1} \text {. Nutrient } \\
\text { considered limiting (primary) in } \\
\text { river systems - linked to } \\
\text { eutrophication risk (can cause } \\
\text { harmful algal blooms). }\end{array}$ & $\begin{array}{l}\text { Naturally occurring element which } \\
\text { has been extensively mined from } \\
\text { geological deposits. Phosphorus is } \\
\text { then converted and used } \\
\text { predominantly as fertilizers applied } \\
\text { in agriculture. It gets transferred } \\
\text { from agricultural land to river } \\
\text { systems if applied in excess. } \\
\text { Phosphorus is also abundant in } \\
\text { human and industrial waste and } \\
\text { household products } \\
>\text { Considered diffuse and point- } \\
\text { source pollutant }\end{array}$ & $\begin{array}{l}\text { - EC Urban } \\
\text { Wastewater } \\
\text { treatment Directive } \\
(91 / 271 / E E C) \\
\text { - } 1992 \text { French water } \\
\text { law }\left(n^{\circ} 92-3\right) \\
\text { - EU-WFD } \\
\text { (2000/60/EC) } \\
\text { - French law } n^{\circ} \text { 2004- } \\
338 \\
\text { - French "LEMA" law } \\
n^{\circ} 2006-1772 \\
\text { - French Decree } \\
n^{\circ} 2007-491 \text { banning } \\
\text { phosphates in } \\
\text { domestic detergents }\end{array}$ \\
\hline $\begin{array}{l}\text { Nitrates } \\
\text { (code } 1340 \text { in } \\
\text { the Naïades } \\
\text { database) }\end{array}$ & $\begin{array}{l}\text { Expressed as } \mathrm{mg} \mathrm{N} \mathrm{L}^{-1} \text {. Highly } \\
\text { mobile nutrient, considered limiting } \\
\text { in some environments - linked to } \\
\text { eutrophication risk (can cause } \\
\text { harmful algal blooms) and drinking } \\
\text { water contamination (harmful } \\
\text { human health effects) }\end{array}$ & $\begin{array}{l}\text { Naturally occurring form of nitrogen } \\
\text { fixed from gaseous nitrogen }\left(\mathrm{N}_{2}\right) \text { by } \\
\text { organisms or industrial processes. } \\
\text { This conversion allows it to be } \\
\text { assimilated by plants. Industrial } \mathrm{NO}_{3} \\
\text { synthesis has proliferated the } \\
\text { quantity of } \mathrm{NO}_{3} \text { applied to } \\
\text { agricultural land to increase crop and } \\
\text { animal product yield - } \mathrm{NO}_{3} \text { can be } \\
\text { transported from such land to rivers } \\
\text { if applied excessively. } \mathrm{NO}_{3} \text { also } \\
\text { abundant in wastewater (human and } \\
\text { industrial waste). } \\
\text { > Considered diffuse and point- } \\
\text { source pollutant }\end{array}$ & $\begin{array}{l}\text { - Groundwater } \\
\text { Directive } \\
\text { (80/68/EEC), } \\
\text { superseded by the } \\
\text { revised Groundwater } \\
\text { Directive } \\
\text { (2006/118/EC) } \\
\text { - EC Nitrates Directive } \\
\text { (91/676/EEC) } \\
\text { - EC Urban } \\
\text { Wastewater } \\
\text { treatment Directive } \\
\text { (91/271/EEC) } \\
\text { - 1992 French water } \\
\text { law (n92-3) } \\
\text { - EU-WFD } \\
\text { (2000/60/EC) } \\
\text { - French law n²004- } \\
338 \\
\text { - French "LEMA" law } \\
n^{\circ} 2006-1772\end{array}$ \\
\hline
\end{tabular}

We completed our statistical model and interpretation with some high-level concentration-discharge ( $\mathrm{C}-\mathrm{Q}$ ) analysis of the long-term data to infer the sources (point or 295 diffuse sources) of TP and $\mathrm{NO}_{3}$ concentrations, as both parameters can be attributed to either 
short-term rainfall or storm events to determine the source of contaminants within a river basin (Bieroza et al., 2018), either observing the dilution (indication of point-sources) or concentration (indication of diffuse sources) of those contaminants over time with increasing discharge. We used monthly mean $90^{\text {th }}$ percentile C-Q data from 2010 to 2018 for this analysis.

\subsubsection{Independent variables: relative presence of interest groups}

We built our independent variables from the minutes of river basin committee meetings. Attendance was tracked in a database where each observation represents one individual at one specific meeting. We excluded state representatives from that dataset as different rules of attendance apply to them.

We focus our attention on the ratio of presence between three main interest groups: the agricultural interests (i.e. representatives from agriculture, irrigation and industrial food cooperatives), the industrial interests (i.e. representatives from all forms of industries, water utilities, electricity providers and SMEs) and Non-Governmental Organizations (NGOs) or noneconomic interests (i.e. representatives from environmental NGOs, water consumers, fishermen NGOs and water sport NGOs). Sub-groups were merged together only if a shared interest could be clearly established between them, based on official documentation and interviews conducted. Individual members from other groups might also share these interests (e.g. local authority representatives can also be farmers), but no method allowed us to systematically identify them. As such, the presence of certain interest groups might be underestimated. present $\left._{A, y}\right)$ :

For each group $(A)$ and each year $(y)$, we calculated the following indicator (\%

\subsubsection{Control variables}

As mentioned earlier, previous research on river basin partnerships underlines the importance of technical and financial capacity of governance bodies (Leach and Pelkey 2001; Scott 2016; Biddle 2017). Therefore, we controlled for historical changes in the income of river basin agencies (Agences de l'eau), adjusted for inflation with the OECD consumer price index.

Previous research also includes ecological or physical controls (Scott, 2015; Scott, 2016), such as the average land use in the basin. For each basin, we calculated the average land use ratio between the main first-level categories of the CLC dataset - namely, artificial 
soils, agricultural land, forest and semi-natural areas and wetland - assuming a linear progression between the measurement years available in CLC (i.e. 1990, 2000, 2006, 2012, 2018). The links between land-use and surface water quality are complex. Historically, there has been strong links between urbanisation (McGrane, 2016) and agricultural intensification (Mateo-Sagasta et al., 2017), both typically increasing pollutant concentrations (e.g. Mattikalli and Richards 1996). From our data exploration, we chose to retain only the ratio of artificial land to control for the evolution of land use in our statistical model. We consider this variable to be representative of a territory getting more urbanised, densely populated and richer.

Climate and weather patterns (i.e. precipitation or dry-spells) influence flow; considered the master variable of river systems. This can drive spatial and temporal changes in water quality, whilst interacting with complex societal changes within SESs. We capture this aspect using historical changes in the average annual flow ("écoulement annuel moyen" in French) at a representative station selected to be located at the lowest possible part of the drainage area (outflow) for each river basin with data covering the study's timestep. These data were accessed on the French "Hydro" database. Representative stations are respectively located in Montjean-sur-Loire in LB (Hydro code M5300010) and Vernon in SN (Hydro code H8100020).

Our controls for ecological outcomes are in line with practices from previous studies on how institutions can impact rivers (Bernauer and Kuhn, 2010). We tested the inclusion of several land use types (from the CLC database), the evolution of Gross Domestic Product per capita and the population density as additional control variables. However, we detected strong multicollinearity concerns and opted not to include them. This restrictive choice was also motivated by our sample size, limiting the number of coefficients included reliably.

\subsection{Statistical analysis}

We run the models separately on the three dependent variables of interest, as was done by Scott (2015). Based on the empirical context and theoretical insights, we can expect a delay in the ecological outcomes of institutional factors of more than a year, so we computed a temporal lag in our data. Previous similar studies assume this delay to be three to four years (Scott 2016; Scott 2015), and we added an additional lag of five years. We tested all models for all three lag-times. This gave us the total of nine final models, i.e. three different year lags $(+3,+4,+5)$ for our three dependent variables (BOD5, TP, $\left.\mathrm{NO}_{3}\right)$. Considering the structure of our data (observation by basin per year), a natural model specification is to include both river basin and year effects. Alternative models (econometric panel data analysis and Generalized Linear Mixed Models -or GLMM- more common in ecology) were trialled on the three separate dependent variables to select the best procedure to follow. We opted for using GLMM as it was more statistically robust for dealing with non-normal ecological data (Bolker et al., 2009) and more flexible to our specific panel configuration, containing a number of complex predictors. All analyses were run on R (version 3.5.2), using the Ime4, plm and stargazer packages (Croissant and Millo 2008; Bates et al., 2015; Hlavac, 2018). 
Gamma family GLMM was fitted to our dependent variables, as they are continuous, non-negative (and non-zero) and right-skewed in distribution. The log link-function was chosen based on the resulting sample-size corrected Akaike Information Criterion (AICC) and model validation, when compared to the package's default link-function (inverse). We rescaled the flow and water agency income variables.

\subsection{Model validation}

Prior to model specification, we followed a data exploration protocol fit for GLMMs (Zuur et al, 2010). Visual exploration of the data did not reveal any problematic outliers. We explored the residuals to validate our models (Zuur and leno 2016). The residuals for all of the models were largely distributed normally, which is necessary for a good model fit. Plots of residual distribution are included in annex of this paper (Figures $A 1$ and A2). However, all nine models did not fit equally well, as was the case for the lag $5 \mathrm{BOD} 5$ and lag $3 \mathrm{NO}_{3}$ models. This could not be fully resolved using the gamma family distribution. Plots of residuals vs. fitted response variable appeared to display no clear patterns and a relatively equal distribution below and above zero. Mild clustering was seen below the zero line in the lag 5 models and some of the lag $4\left(\mathrm{NO}_{3}\right)$, meaning that some slight underestimation of the dependent variable could be possible. All issues with fit were a product of fitting models to highly right-skewed data (BOD5 and TP) or incorporating the time lag into non-normal data analyses $\left(\mathrm{NO}_{3}\right)$. Gamma distributions were the best in dealing with this (i.e. lowest AICc) compared to other distributions trialled (gaussian).

\section{Results}

\subsection{Descriptive statistics}

The trends of historical concentration of the three dependent variables for both river basins are represented in Figure 4. Reductions in the annual mean concentrations can be seen across both catchments for BOD5 and TP. Conversely, a clear increase over time can be seen for $\mathrm{NO}_{3}$ concentrations in $\mathrm{SN}$. A more gradual and variable increase in $\mathrm{NO}_{3}$ concentrations was seen in LB, followed by stagnation after the year 2000. The descriptive statistics of our variables, presented in Table 3 and Table 4 are drawn on the dataset with a 3-year lag. Only social variables are lagged. As can be seen in Table 4, collinearity is a potential concern for these data, which we controlled for by running VIF analysis on our model results. 


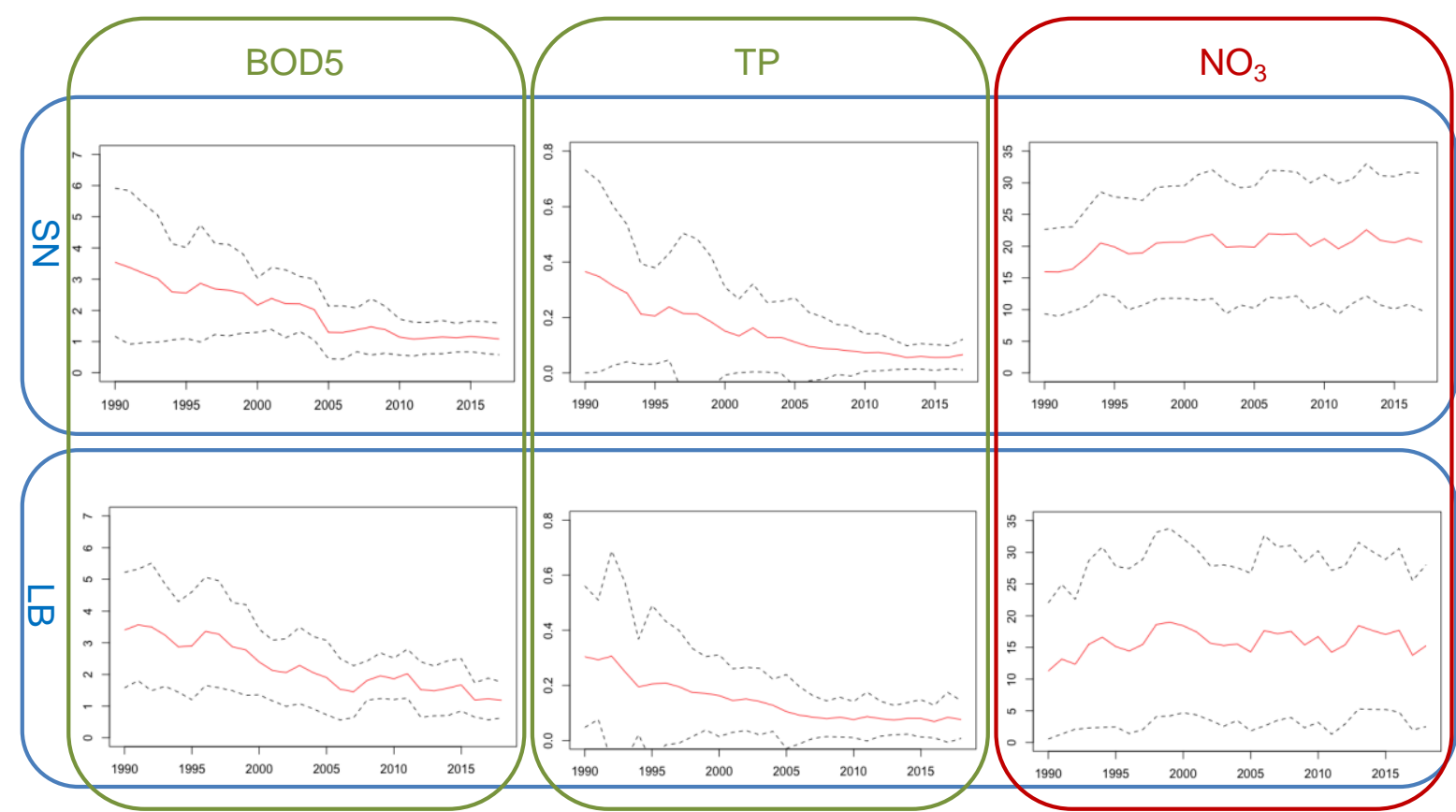

Figure 4. Trends of mean concentrations in $\mathrm{mg} \mathrm{L}^{-1}$ (red line) and upper and lower standard deviations limits (1SD; dashed line) for the three ecologically relevant water quality parameters.

Table 3. Descriptive statistics of the 3-year lag scenario. Variables marked with an (I) are lagged.

\begin{tabular}{lccccccc}
\hline Statistic & $\boldsymbol{n}$ & Mean & SD & Min & Pctl(25) & Pctl(75) & Max \\
\hline BOD5 mean & 57 & 2.12 & 0.79 & 1.08 & 1.38 & 2.77 & 3.56 \\
$\mathrm{NO}_{3}$ mean & 57 & 17.98 & 2.78 & 11.30 & 15.53 & 20.52 & 22.59 \\
TP mean & 57 & 0.15 & 0.08 & 0.06 & 0.08 & 0.20 & 0.37 \\
\% artificial soil & 57 & 0.06 & 0.01 & 0.04 & 0.05 & 0.07 & 0.07 \\
Mean annual flow & 55 & 633.36 & 260.59 & 300.00 & 422.50 & 782.00 & $1,390.00$ \\
Annual water agency income (I) & 55 & 83.15 & 62.35 & 15.75 & 43.54 & 124.40 & 227.28 \\
\% present agriculture (I) & 56 & 0.08 & 0.03 & 0.03 & 0.06 & 0.10 & 0.17 \\
\% present industry (I) & 56 & 0.23 & 0.05 & 0.14 & 0.19 & 0.27 & 0.34 \\
\% present NGOs (I) & 56 & 0.14 & 0.05 & 0.06 & 0.10 & 0.18 & 0.24 \\
\hline
\end{tabular}

Table 4. Pearson correlations coefficients for the 3-year lag database.

\begin{tabular}{|c|c|c|c|c|c|c|c|c|c|}
\hline & & (2) & (3) & (4) & (5) & (6) & (7) & (8) & (9) \\
\hline (1) & BOD5 mean & $-0.485 * * *$ & $0.928 * * *$ & $-0.472 * * *$ & 0.015 & $-0.325 * *$ & -0.073 & $0.351^{* * *}$ & $-0.863 * * *$ \\
\hline (2) & NO3 mean & 1.000 & $-0.403 * * *$ & $0.805^{* * *}$ & -0.169 & $0.734 * * *$ & $-0.368 * * *$ & $0.461 * * *$ & $0.234 *$ \\
\hline (3) & TP mean & & 1.000 & $-0.266 * *$ & -0.170 & $-0.254 *$ & -0.221 & $0.450 * * *$ & $-0.803 * * *$ \\
\hline (4) & $\%$ artificial soil & & & 1.000 & $-0.610 * * *$ & $0.763 * * *$ & $-0.637 * * *$ & $0.525 * * *$ & $0.331 * *$ \\
\hline \multirow[t]{2}{*}{ (5) } & Mean annual flow & & & & 1.000 & $-0.403 * * *$ & $0.536 * * *$ & $-0.420 * * *$ & -0.140 \\
\hline & Annual water agency & & & & & & & & \\
\hline (6) & income (I) & & & & & 1.000 & $-0.489 * * *$ & $0.556 * * *$ & 0.149 \\
\hline (7) & $\%$ present agriculture (I) & & & & & & 1.000 & $-0.720 * * *$ & 0.171 \\
\hline (8) & $\%$ present industry (I) & & & & & & & 1.000 & $-0.475 * * *$ \\
\hline (9) & $\%$ present NGOs (I) & & & & & & & & 1.000 \\
\hline
\end{tabular}




\subsection{Model results}

The model results can be seen in Table 5. Relating to our first hypothesis, we see that the ratio of presence of the three interest groups have significantly different impacts on the ecologically relevant indicators studied. Controlling for other influences, we find that a higher percentage of NGO representatives present in basin committee meetings is linked to significantly lower concentration levels of BOD5 and TP across all the model lags. The ratio of NGO representatives, therefore, seems to come with a positive effect in terms of water quality improvements towards legislative targets. Interestingly, linked to our second hypothesis, the effect of NGOs is different for $\mathrm{NO}_{3}$ as a response variable, displaying no significant effect for 3 and 4 years of lag, and a significantly positive effect for the 5 -year lag. Conversely, a higher share of industry representatives is related to significantly higher levels of all three response variables (lag-dependent). Finally, stronger participation by agricultural interests has no significant relationship with BOD5 concentrations, but a significant positive link to TP on the 5-year lag. Most importantly, a higher representation of agricultural interests was linked to increases in concentrations of $\mathrm{NO}_{3}$ across all lags, though only shorter lag times were significant ( 3 and 4 years).

As hinted at by our exploratory descriptive data approach, the concentration of $\mathrm{NO}_{3}$ behaves differently over time from the BOD5 and TP. The effect of artificial land use is mostly the opposite for $\mathrm{NO}_{3}$, compared with $\mathrm{BOD} 5$ and TP. We interpret this as being linked to the social-ecological drivers behind the sources of these parameters within the river basins, i.e. the changes in concentration of $\mathrm{NO}_{3}$ is caused by different human activities than those of BOD5 and TP.

Table 5. Results of gamma family GLMM models with log link-function for the dependent vs. independent and control variables.

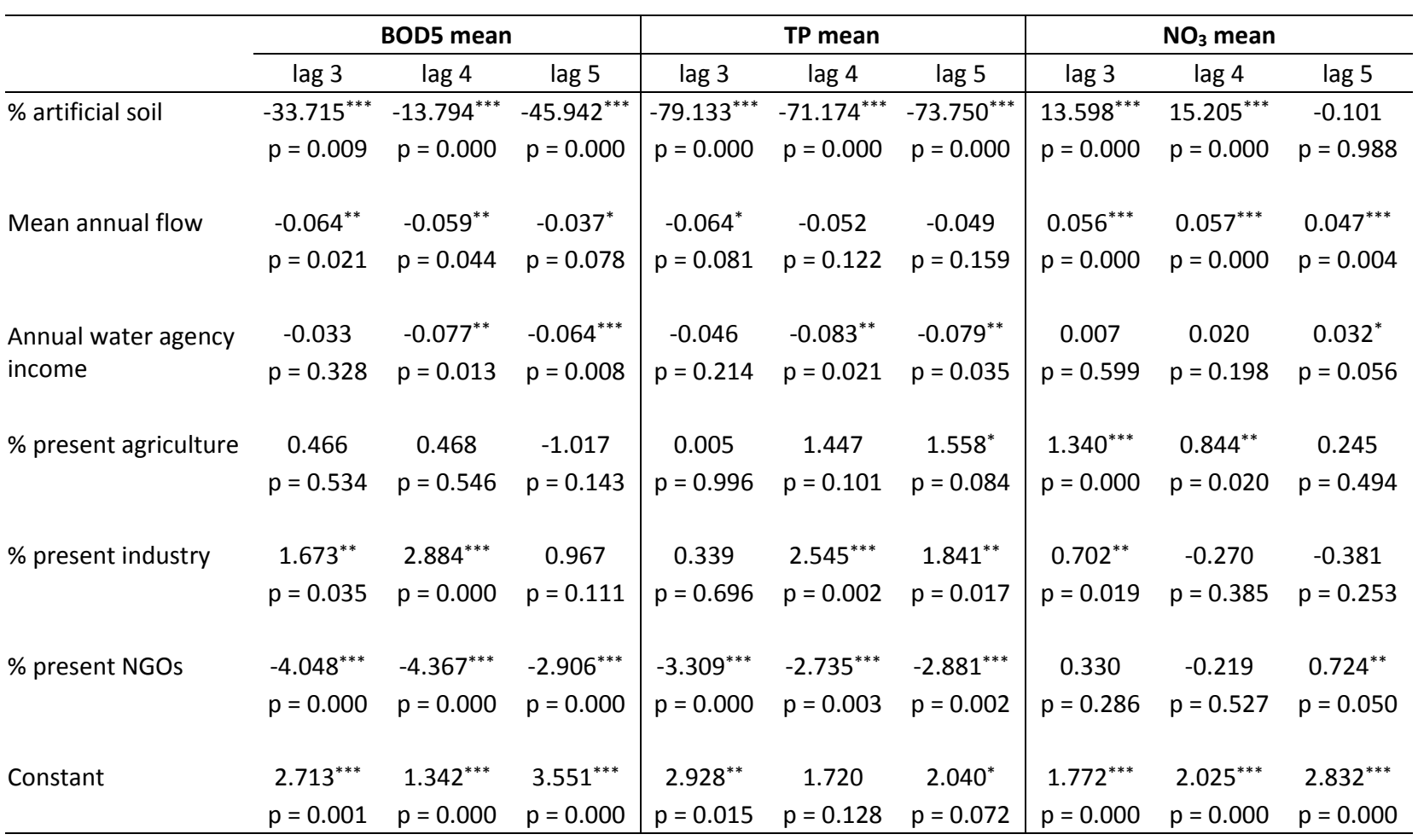




\begin{tabular}{|c|c|c|c|c|c|c|c|c|c|}
\hline$n$ & 55 & 55 & 55 & 55 & 55 & 55 & 55 & 55 & 55 \\
\hline Log Likelihood & 5.694 & 5.815 & 4.152 & 145.158 & 147.228 & 146.741 & -66.653 & -72.548 & -74.459 \\
\hline Akaike Inf. Crit. & 8.612 & 8.371 & 11.696 & -270.316 & -274.457 & -273.481 & 153.307 & 165.096 & 168.919 \\
\hline
\end{tabular}

448

449

450

451

452

453

454

455

456

457

458

459

460

461

462

463

464

465

466

467

468

469

470

471

472

473

474

475

476

477

478

479

480

481

482

483

484

We therefore undertook a high-level $\mathrm{C}-\mathrm{Q}$ analysis to clarify our interpretation regarding the sources of $\mathrm{TP}$ and $\mathrm{NO}_{3}$ that could be influenced by both point and diffuse sources. This analysis (Figure A3 and Table A1 in annex) linked higher mean monthly flow with lower TP concentrations, suggesting point-source pollution, and the converse trend for $\mathrm{NO}_{3}$, suggesting a diffuse source origin. The model results in Table 5 (for the entire database timescale) are consistent with this $\mathrm{C}-\mathrm{Q}$ analysis, demonstrating that basin-wide and annualtimescale $C-Q$ analyses can be informative (Rose et al., 2018).

Finally, on the financial capacity of water agencies, higher income has a clear, significant link to lower concentrations of BOD5 and TP for lags 4 and 5. We draw from this result that the time necessary for the income to have an impact is closer to 4 or 5 years than 3. The order of magnitude of the overall lag between participatory processes and ecological outcomes on these indicators (i.e. 3 to 5 years) is in line with previous findings (Scott 2016; Scott 2015). In the case of $\mathrm{NO}_{3}$, water agency income barely has any effect until the 5 -year lag, when it has a significant positive effect on $\mathrm{NO}_{3}$ concentrations.

\section{Discussion}

This study is the first, to our knowledge, using long-term water quality data to statistically outline the ecological outcomes linked to the relative presence of different interest groups in collaborative governance processes. As seen in the results, we do detect an ecological effect of the relative space taken by different interest groups in deliberations. This effect varies depending on the dependent variable considered.

Our model control results and additional $\mathrm{C}-\mathrm{Q}$ analysis indicate that the observed $\mathrm{NO}_{3}$ concentrations, in contrast to TP and BOD5, are linked to diffuse water pollution, and most probably to agricultural activities (Bouleau et al. 2020). As mentioned in table 2, excess fertiliser and animal waste applications to agricultural land have long been recognised as a driver of $\mathrm{NO}_{3}$ export from land to ground and surface waters (Singh and Sekhon, 1979; Boyer et al., 2002; Howden et al., 2011). Meanwhile, point sources (e.g. wastewater effluent discharge) were likely driving river basin concentrations of BOD5 and TP, as determined by theoretical insights (table 2 ) and the $\mathrm{C}-\mathrm{Q}$ analysis.

Regarding financial capacity, higher agency income was linked to lower concentrations of BOD5 and TP, whilst this was not the case for $\mathrm{NO}_{3}$. This supports the idea that costly, yet effective point-source mitigation may be responsible for the decreasing BOD5 and TP trends over time (Figure 4). These mitigation measures could include the funding of wastewater treatment development as well as the increased taxation of certain polluting activities, incentivizing polluters to invest in cleaner practices. Investment to reduce $\mathrm{NO}_{3}$ concentrations, however, has either not been sufficiently allocated towards managing diffuse sources, or 
investment in diffuse source management is generally less efficient at reducing $\mathrm{NO}_{3}$ concentrations. Discussions around the financial cost of reducing DWPA are ongoing in countries with a high proportion of river basin farmland. A recent study focused on agriculture in England (UK) suggested that a $£ 52$ per hectare investment was required, at the national scale, to reduce $\mathrm{NO}_{3}$ export to rivers by $2.5 \%$ (Collins et al., 2018). Compared to investments in point-source management strategies, this cost per reduction of $\mathrm{NO}_{3}$ could be considered minimal. However, one needs to consider the uncertainty of DWPA mitigation (e.g. the standard deviations associated with $\mathrm{NO}_{3}$ concentrations compared to BOD5 and TP in Figure 4 ) and the vast areas of land potentially requiring investment (see extent of agricultural landcover in Table 1). Therefore, compared to previous studies, our paper describes a nuanced impact of financial capacity on ecological outcomes during collaborative governance processes (Scott 2016; Biddle 2017).

Our models link a higher ratio of presence of NGO representatives in basin committee meetings to reductions in BOD5 and TP, but shows no positive effect for $\mathrm{NO}_{3}$ pollution. These results could indicate that the influence of NGO representatives is most effective in deliberations when the issue at hand has a shared problem definition that is already established and relatively certain solutions (i.e. investment in better wastewater treatment technology), requiring more coordination than cooperation (Bodin 2017). We acknowledge the role of national and supra-national legislation in driving the wider governance of wastewater, for example, and how this likely positively influenced TP and BOD5 concentrations (see Table 2).

Conversely, in terms of trends, higher ratios of agricultural representatives in river basin committee meetings had a significant positive link with higher $\mathrm{NO}_{3}$ concentrations. As mentioned earlier, in a context of shared understanding and social learning, an increased involvement of agricultural representatives could have led to reduced $\mathrm{NO}_{3}$ pollution, through an easier acceptability and implementation of mitigation measures (Newig et al. 2018). However, our data shows no sign of such an effect and exactly the opposite, pointing to the possibility of power struggle (Selznick, 1949; Behagel and Arts, 2014). We do not have longitudinal data on the existence of power struggles, however, future research should be done to confirm statistically the role of power dynamics in this arena. We also acknowledge that practices contributing to NO3 pollution in the catchments may have been improved due to national and supra-national legislation (see Table 2), but these effects are not seen in our data.Potentially, there is a longer lag to observe ecological outcomes regarding diffuse pollution sources, compared to point-sources. Reasons behind this are complex and relate to the geographical extent of diffuse pollutant sources and the properties of specific pollutants (Biddulph et al., 2017; Haygarth et al., 2014).

Nonetheless, our results highlight the challenge collaborative governance institutions face with managing diffuse water pollution, and more specifically DWPA. Globally, managing DWPA is practically and legally challenging, especially across large or transnational river basins (Novotny, 1999; Wang, 2006; Duncan, 2017). Although France has pioneered high levels of actor participation within river basin management in Europe, $\mathrm{NO}_{3}$ and pesticides are now the 
main causes of drinking water abstraction closures across French river basins due to poor water quality (DGS, 2012). In the case of DWPA, the involvement of agricultural stakeholders alone is not enough to yield desirable ecological outcomes. Previous research hints that the most effective pattern of stakeholder involvement is not necessarily a broad and inclusive approach but rather a smaller selection of key actors (Ulibarri and Scott 2017). Collaborative processes playing out at a smaller geographical scale than the basin could also yield better results (Pellegrini, Bortolini, and Defrancesco 2019). Overall, our results point to the importance of governance learning in collaborative river basin governance, and especially for the EU WFD (Challies et al. 2017).

Overall in collaborative governance, the question of the composition of the room for deliberations is of high ecological relevance and remains a needed topic of investigation. Indeed, deliberations in collaborative governance can be as much an arena of power struggles (Selznick, 1949; Behagel and Arts, 2014) as a room where a shared understanding of the common good is created (Ansari et al., 2013; Fan and Zietsma, 2017).

\section{Conclusion}

This paper brings together valuable and unexploited sources of information on the history of French collaborative river basin governance, merging data collected using methods from the social and natural sciences.

This novel analysis indicates that, in a context of collaborative governance, different meeting compositions lead to different ecological outcomes. Indeed in our empirical context, a stronger presence of NGO representatives was linked to lower levels of point-source pollution, while a stronger presence of agricultural representatives was linked to higher nitrate pollution. These specific effects are likely to differ in different social and ecological contexts. They nonetheless indicate that future studies on the ecological outcomes of collaborative governance should not limit their explanatory variables to the structure of participatory processes, or to an overall level of stakeholder involvement. On the contrary, such analysis to include the relative weight taken to different interest groups, and should strive to assess power dynamics, in spite of the methodological challenges it represents. Indeed, deliberatory meetings can be as much rooms for shared understanding and social learning as arenas of power struggles.

Further, we underline that the choice of the ecological indicators considered is key. In the case of river basin management, power dynamics between stakeholders seem to be most critical when dealing with matters of diffuse source pollution. Finding the right balance in this case is complicated since tackling this form of pollution requires more engagement from relevant stakeholders than point-source pollution. Indeed, both financial means and regulatory changes seem less effective in tackling diffuse pollution compared to point-source pollution.

\section{Limitations and future research}


For this study, obtaining historical trends of the evolution of ecologically relevant indicators has been challenging. This shows that collaborative governance actors take 568 decisions with little or fragmented feedback on the impact of past decisions to ecosystems.

569 Due to this, and to our ambition to establish a longitudinal statistical analysis, we did not delve 570 in detail in the content of basin committee meetings, e.g. how behaviours evolved among 571 different interest groups, and how these behaviours translated in different measures being 572 voted. Our data do not allow us to measure through time if power struggles or social learning 573 appeared between groups, therefore missing out on a potentially important mediating 574 variable, and not allowing us to identify the precise mechanism of influence. Such an analysis

575 would be of high academic and practical relevance.

Our dataset includes only two river basins; both with a relatively small final sample size and located in the same country. Although different in important aspects, the two basins remain of a similar geographical scale and do not deal extensively with water scarcity issues. We hope to see similar studies try to replicate our results in other SESs to see how collaborative governance dynamics fit in a different ecological context (Bodin 2017). Considerations of hydromorphological issues could also be interesting (Kristensen, Whalley, and Klančnik 2018). Most importantly, we would invite future research to study the outcomes of collaborative governance via the inclusion of large, long-term, indicator species datasets, as a better proxy for ecosystem and ecological condition.

The participation of actors in river basin committees is not the only factor explaining progress in reducing point-source pollution. As mentioned in our analysis, we assume the improvements made on BOD5 and TP concentrations to be also linked to national and supranational regulation, such as the EU Wastewater Directive of 1992 or the French Decree (2007) banning phosphate-containing detergents. The impact of regulation could be more robustly linked to changes in ecological conditions through interdisciplinary work. 


\section{References}

592

593

594

595

596

597

598

599

600

601

602

603

604

605

606

607

608

609

610

611

612

613

614

615

616

617

618

619

620

621

622

623

624

625

626

627

628

629

630

631

632

Agrawal, A., Chhatre, A., 2011. Against Mono-Consequentialism: Multiple Outcomes and Their Drivers in Social-Ecological Systems. Global Environmental Change 21(1): 1-3.

Ansari, S., Wijen, F., Gray, B., 2013. Constructing a Climate Change Logic: An Institutional Perspective on the "Tragedy of the Commons." Organization Science 24(4): 10141040.

Ansell, C., Gash A., 2008. Collaborative Governance in Theory and Practice. Journal of Public Administration Research and Theory 18(4): 543-571.

Barataud, F., Durpoix, A., \& Mignolet, C. 2014. Broad analysis of French priority catchment areas : A step toward adaption of the Water Framework Directive? Land Use Policy, 36, 427- 440.

Bates, D., Maechler, M., Bolker, B., Walker, S., 2015. Fitting linear mixed-effects models using Ime4. Journal of Statistical Software. 67(1): 1-48.

Bates, B.C., Kundzewicz, Z.W., Shaohong, W., Palutikof, J.P., (eds) 2008. Climate change and water. Technical Paper of the Intergovernmental Panel on Climate Change. IPCC Secretariat, Geneva. https://www.ipcc.ch/site/assets/uploads/2018/03/climatechange-water-en.pdf

Baudoin, L., Arenas, D., 2020. From Raindrops to a Common Stream: Using the SocialEcological Systems Framework for Research on Sustainable Water Management. Organization \& Environment, 33(1), 126- 148.

Behagel, J.H., Arts, B., 2014. Democratic governance and political rationalities in the implementation of the Water Framework Directive in the Netherlands. Public Administration 92(2): 291-306.

Bernauer, T., Kuhn, P., 2010. Is There an Environmental Version of the Kantian Peace? Insights from Water Pollution in Europe. European Journal of International Relations 16(1): 77-102.

Biddulph, M., Collins, A. L., Foster, I. D. L., \& Holmes, N. 2017. The scale problem in tackling diffuse water pollution from agriculture : Insights from the Avon Demonstration Test Catchment programme in England. River Research and Applications, 33(10), 1527- 1538.

Bieroza, M. Z., Heathwaite, A. L., Bechmann, M., Kyllmar, K., Jordan, P., 2018. The concentration-discharge slope as a tool for water quality management. Science of the Total Environment. 630: 738-749.

Biddle, J.C., 2017. Improving the Effectiveness of Collaborative Governance Regimes: Lessons from Watershed Partnerships. Journal of Water Resources Planning and Management 143(9): 4017048.

Biddle, J.C., Koontz, T.M., 2014. Goal Specificity: A Proxy Measure for Improvements in Environmental Outcomes in Collaborative Governance. Journal of Environmental Management 145: 268-276.

Bodin, Ö., 2017. Collaborative Environmental Governance: Achieving Collective Action in Social-Ecological Systems. Science 357(6352): eaan1114. 
Boeuf, B., Fritsch, O., 2016. Studying the Implementation of the Water Framework Directive in Europe: A Meta-Analysis of 89 Journal Articles. Ecology and Society 21(2).

Bolker, B.M., Brooks, M.E., Clark, C.J., Geange, S.W., Poulsen, J.R., Stevens, M.H.H., White, J.S.S. 2009. Generalized linear mixed models: A practical guide for ecology and evolution. Trends in Ecology \& Evolution, 24(3), 127- 135.

Bouleau, G., Barbier, R., Halm-Lemeille, M.-P., Tassin, B., Buchs, A., Habets, F., 2020. Despite Great Expectations in the Seine River Basin, the WFD Did Not Reduce Diffuse Pollution. 13(3), 22.

Boyer, E.W, Goodale, C.L, Jaworski, N.A, Howarth, R.W., 2002. Anthropogenic nitrogen sources and relationships to riverine nitrogen export in the north-eastern USA. Biogeochemistry. 57(58):137-169.

Cashman, A., Lewis, L., 2007. Topping up or Watering down? Sustainable Development in the Privatized UK Water Industry. Business Strategy and the Environment 16(2): 93-105.

Challies, E., Newig, J., Kochskämper, E., \& Jager, N. W. 2017. Governance change and governance learning in Europe : Stakeholder participation in environmental policy implementation. Policy and Society, 36(2).

Collins, A. L., Newell Price, J.P. Zhang, Y. Gooday, R. Nade, P.S., Skirvin, D., 2018. Assessing the potential impacts of a revised set of on-farm nutrient and sediment 'basic' control measures for reducing agricultural pollution across England. Science of the Total Environment. 621: pp.1499-1511.

Croissant, Y., Millo, G., 2008. Panel Data Econometrics in R : The PIm Package. Journal of Statistical Software 27(2). http://www.jstatsoft.org/v27/i02/, accessed January 8, 2020.

Dalgaard, T., Hansen B., Hasler B., et al. 2014. Policies for Agricultural Nitrogen Management-Trends, Challenges and Prospects for Improved Efficiency in Denmark. Environmental Research Letters 9(11): 115002.

DGS - Direction Générale de la Santé, 2012. Abandons de captages utilisés pour la production d'eau destinée à la consommation humaine - Bilan Février 2012, https://solidarites-sante.gouv.fr/IMG/pdf/bil0212.pdf accessed January 10, 2020

Duncan, R., 2017. The challenges of regulating diffuse agricultural pollution to improve water quality. Case Studies in the Environment. 1(1): pp.1-7.

Emerson K., Nabatchi T., 2015. Evaluating the Productivity of Collaborative Governance Regimes: A Performance Matrix. Public Performance \& Management Review 38(4): 717-747.

Emerson K., Nabatchi T., Balogh S., 2012. An Integrative Framework for Collaborative Governance. Journal of Public Administration Research and Theory 22(1): 1-29.

European Commission, and Directorate-General for the Environment, 2003. Public Participation in Relation to the Water Framework Directive No 8. No 8. Luxembourg: OPOCE. http://bookshop.europa.eu/uri?target=EUB:NOTICE:KH5103221:EN:HTML, accessed December 12, 2017.

Fan, G.H., Zietsma, C., 2017. Constructing a Shared Governance Logic: The Role of Emotions in Enabling Dually Embedded Agency. Academy of Management Journal, 60(6), 
Graversgaard, M., Jacobsen B., Kjeldsen C., Dalgaard T., 2017. Stakeholder Engagement and Knowledge Co-Creation in Water Planning: Can Public Participation Increase CostEffectiveness? Water 9(3): 191.

Graversgaard, M., Hedelin, B., Smith, L., Gertz, F., Højberg, A. L., Langford, J., Martinez, G., Mostert, E., Ptak, E., Peterson, H., Stelljes, N., van den Brink, C., \& Refsgaard, J. C. 2018. Opportunities and Barriers for Water Co-Governance-A Critical Analysis of Seven Cases of Diffuse Water Pollution from Agriculture in Europe, Australia and North America. Sustainability, 10(5), 1634.

Hardy, C., Phillips N., 1998.Strategies of Engagement: Lessons from the Critical Examination of Collaboration and Conflict in an Interorganizational Domain. Organization Science 9(2): 217-230.

Harley, C., Metcalf L., Irwin J., 2014. An Exploratory Study in Community Perspectives of Sustainability Leadership in the Murray Darling Basin. Journal of Business Ethics 124(3): 413-433.

Harrison, S., McAree C., Mulville W., Sullivan T., 2019. The Problem of Agricultural 'Diffuse' Pollution: Getting to the Point. Science of The Total Environment 677: 700-717.

Haycock, N.E., Muscutt A.D., 1995. Landscape Management Strategies for the Control of Diffuse Pollution. Landscape and Urban Planning 31(1-3): 313-321.

Haygarth, P. M., Jarvie, H. P., Powers, S. M., Sharpley, A. N., Elser, J. J., Shen, J., Peterson, H. M., Chan, N.-I., Howden, N. J. K., Burt, T., Worrall, F., Zhang, F., \& Liu, X. 2014. Sustainable Phosphorus Management and the Need for a Long-Term Perspective : The Legacy Hypothesis. Environmental Science \& Technology, 48(15), 8417- 8419.

Heikkila, T., 2017. Evidence for Tackling the Complexities of Water Governance. Public Administration Review 77(1): 17-20.

Hlavac, M., 2018. stargazer: Well-formatted regression and summary statistics tables [Computer software manual]. Bratislava, Slovakia. Retrieved from https://CRAN.Rproject.org/package=stargazer ( $R$ package version 5.2 .2 )

Howden, N.J.K., Burt, T.P. Worrall, F. Mathias, S.A. Whelan, M.J., 2011. Farming for water quality: Balancing food security and nitrate pollution in UK river basins. Annals of the Association of American Geographers. 103(2). Special Issue: Geographies of Water: pp.397-407.

Jager, N., Challies E., Kochskämper E., et al., 2016. Transforming European Water Governance? Participation and River Basin Management under the EU Water Framework Directive in 13 Member States. Water 8(4): 156.

Jager, N., Jens Newig J., Challies E., and Kochskämper E., 2020. Pathways to Implementation: Evidence on How Participation in Environmental Governance Impacts on Environmental Outcomes. Journal of Public Administration Research and Theory 30(3): 383-399.

Jarvie, H., Sharpley A., Withers P., et al., 2013. Phosphorus Mitigation to Control River Eutrophication: Murky Waters, Inconvenient Truths, and "Postnormal" Science. Journal of Environmental Quality 42(2): 295-304. 
Kochskämper, E., Challies E., Newig J., Jager N., 2016. Participation for Effective Environmental Governance? Evidence from Water Framework Directive Implementation in Germany, Spain and the United Kingdom. Journal of Environmental Management 181: 737-748.

Koontz, T.M., Thomas C.W., 2006. What Do We Know and Need to Know about the Environmental Outcomes of Collaborative Management? Public Administration Review 66(s1): 111-121.

Kristensen, P., Whalley C., Klančnik K., 2018. European Waters Assessment of Status and Pressures 2018. Copenhagen: European Environment Agency. https://www.eea.europa.eu/publications/state-of-water, accessed August 28, 2020.

Laronde, S., Petit, K., 2010. Bilan national des efforts de surveillance de la qualité des cours d'eau. Onema, Agence Internationale de l'Eau, $330 \mathrm{p}$

Leach, W.D., Pelkey, N.W., 2001, Making Watershed Partnerships Work: A Review of the Empirical Literature. Journal of Water Resources Planning and Management 127(6): 378-385.

Leahey, E., Beckman C., Stanko T., 2017. Prominent but Less Productive: The Impact of Interdisciplinarity on Scientists' Research. Administrative Science Quarterly 62(1): 105-139.

Mateo-Sagasta, J., Zadeh, S. M., Turral, H., Burke, J., 2017. Water pollution from agriculture: a global review. Food and Agricultural Organisation (FAO) Report. Published by the FAO Rome, 2017.

Mattikalli, NM., Richards, K.S., 1996 Estimation of Surface Water Quality Changes in Response to Land Use Change: Application of The Export Coefficient Model Using Remote Sensing and Geographical Information System. Journal of Environmental Management 48(3): 263-282.

McGrane, SJ., 2016. Impacts of Urbanisation on Hydrological and Water Quality Dynamics, and Urban Water Management: A Review. Hydrological Sciences Journal 61(13): 2295-2311.

Morandi, B., Piégay, H., Lamouroux, N., Vaudor, L. 2014. How Is Success or Failure in River Restoration Projects Evaluated? Feedback from French Restoration Projects. Journal of Environmental Management 137: 178-188.

Newig, J., Challies, E, Jager, N.W., Kochskämper, E., Adzersen, A., 2018. The Environmental Performance of Participatory and Collaborative Governance: A Framework of Causal Mechanisms. Policy Studies Journal 46(2): 269-297.

Newig, J., Fritsch O., 2009. Environmental Governance: Participatory, Multi-Level - and Effective? Environmental Policy and Governance 19(3): 197-214.

Novotny, V. 1999. Diffuse pollution from agriculture - A worldwide outlook. Water Science and Technology.39(3): pp.1-13.

Ostrom, E., 1990. Governing the Commons: The Evolution of Institutions for Collective Action. The Political Economy of Institutions and Decisions. Cambridge; New York: Cambridge University Press.

O'Shea, L.,2002. An Economic Approach to Reducing Water Pollution: Point and Diffuse 
Ostrom, E., 2007. A Diagnostic Approach for Going beyond Panaceas. Proceedings of the National Academy of Sciences 104(39): 15181-15187.

Ostrom, E., 2009. A General Framework for Analysing Sustainability of Social-Ecological Systems. Science 325(5939): 419-422.

Pahl-Wostl, C., 2006. Transitions towards Adaptive Management of Water Facing Climate and Global Change. Water Resources Management 21(1): 49-62.

Pauly, D., 1995. Anecdotes and the shifting baseline syndrome of fisheries. Trends in Ecology and Evolution. 10(10):430.

Pellegrini, E., Bortolini, L., \& Defrancesco, E. 2019. Coordination and Participation Boards under the European Water Framework Directive : Different Approaches Used in Some EU Countries. Water, 11(4), 833.

Phillips, N., Lawrence T. B., Hardy C., 2002. Inter-Organizational Collaboration and the Dynamics of Institutional Fields. Journal of Management Studies 37(1)

Purdy, J., 2012. A Framework for Assessing Power in Collaborative Governance Processes. Public Administration Review 72(3): 409-417.

Ran, B., Qi H., 2018. Contingencies of Power Sharing in Collaborative Governance. The American Review of Public Administration 48(8): 836-851.

Reed, M.S., 2008. Stakeholder Participation for Environmental Management: A Literature Review. Biological Conservation 141(10): 2417-2431.

Rice, J., 2013. Controlled Flooding in the Grand Canyon: Drifting Between Instrumental and Ecological Rationality in Water Management. Organization \& Environment 26(4): 412-430.

Rimmert, M., Baudoin, L., Cotta, B., Kochskämper, E., Newig, J., 2020. Participation in River Basin Planning Under the Water Framework Directive - Has it Benefitted Good Water Status? 13(3), 29.

Rose, L.A. Karwan, D.L., Godsey, S. E., 2018. Concentration-discharge relationships describe solute and sediment mobilization, reaction, and transport at event and longer timescales. Hydrological processes 32(18): 2829-2844.

Schielzeth, H., 2010. Simple Means to Improve the Interpretability of Regression Coefficients: Interpretation of Regression Coefficients. Methods in Ecology and Evolution 1(2): 103-113.

Scott, T., 2015. Does Collaboration Make Any Difference? Linking Collaborative Governance to Environmental Outcomes. Journal of Policy Analysis and Management 34(3): 537566.

Scott, T., 2016. Is Collaboration a Good Investment? Modelling the Link Between Funds Given to Collaborative Watershed Councils and Water Quality. Journal of Public Administration Research and Theory 26(4): 769-786.

Scott, T., Ulibarri N., Scott R., 2018. Stakeholder Involvement in Collaborative Regulatory Processes: Using Automated Coding to Track Attendance and Actions: Stakeholder Involvement in Regulation. Regulation \& Governance. 

http://doi.wiley.com/10.1111/rego.12199, accessed February 19, 2020.

801

802

803

804

805

806

807

808

809

810

811

812

813

814

815

816

817

818

819

820

821

822

823

Selznick, P., 1949. TVA and the Grass Roots: A Study of Politics and Organization. Berkeley, Cal.: Univ. of California Press.

Sheppard, C., 1995. Editorial: the shifting baseline syndrome. Marine Pollution Bulletin. 30, pp.766- 767.

Singh, B. Sekhon, G.S., 1979. Nitrate pollution of groundwater from farm use of nitrogen fertilizers - A review. Agriculture and Environment. 4(3): pp.207-225.

Thomas, C., Koontz. T., 2011. Research Designs for Evaluating the Impact of CommunityBased Management on Natural Resource Conservation. Journal of Natural Resources Policy Research 3(2): 97-111.

Tingey-Holyoak, J., 2014. Sustainable Water Storage by Agricultural Businesses: Strategic Responses to Institutional Pressures. Journal of Business Research 67(12): 25902602.

Ulibarri, N., Scott T., 2017. Linking Network Structure to Collaborative Governance. Journal of Public Administration Research and Theory 27(1): 163-181.

Voulvoulis, N., Arpon, K.D., Giakoumis, T., 2017. The EU Water Framework Directive: From great expectations to problems with implementation. Sci. Total Environ. 575, 358366.

Wang, X., 2006. Management of agricultural nonpoint sources pollution in China: current statis and challenges. Water Science and Technology.53(2): pp1-9.

Zuur, A.F., leno, E.N., Elphick, C.S., 2010. A Protocol for Data Exploration to Avoid Common Statistical Problems: Data Exploration. Methods in Ecology and Evolution 1(1): 3-14.

Zuur, A.F., leno, E.N., 2016. A protocol for conducting and presenting results of regressiontype analyses. Methods in Ecology and Evolution, 7(6), 636- 645. 

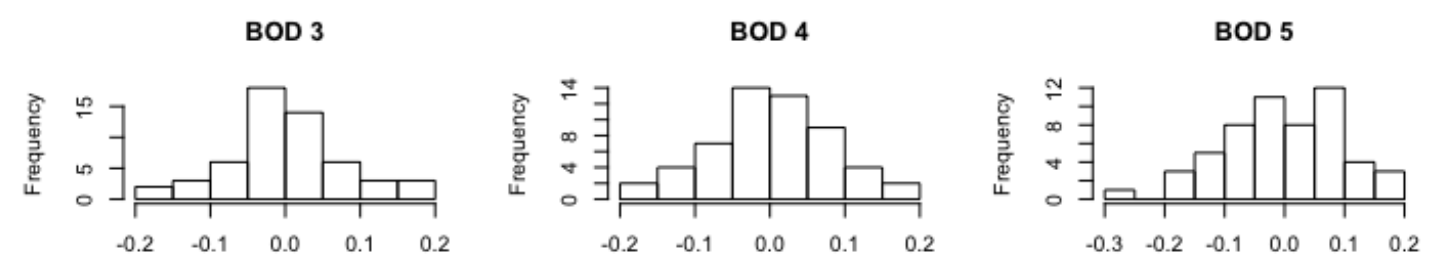

PHOS 3

PHOS 4
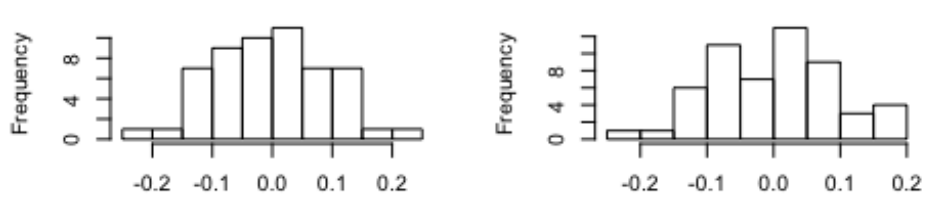

PHOS 5
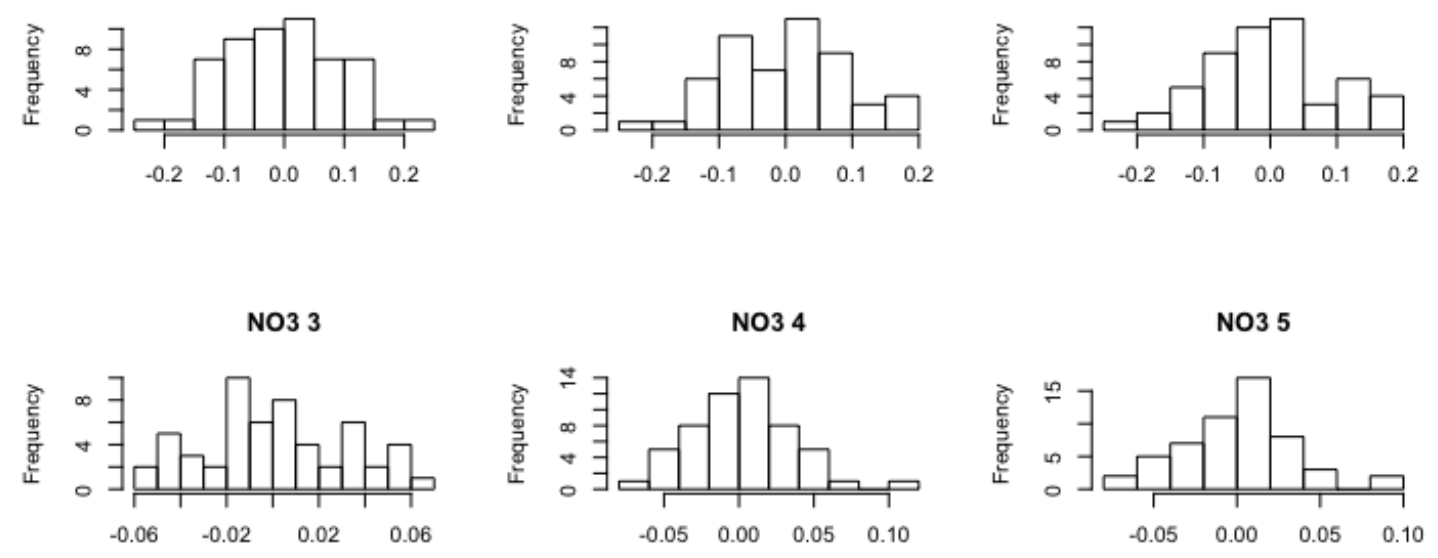

\section{Figure A1}

827

Residual distribution in gamma log models 

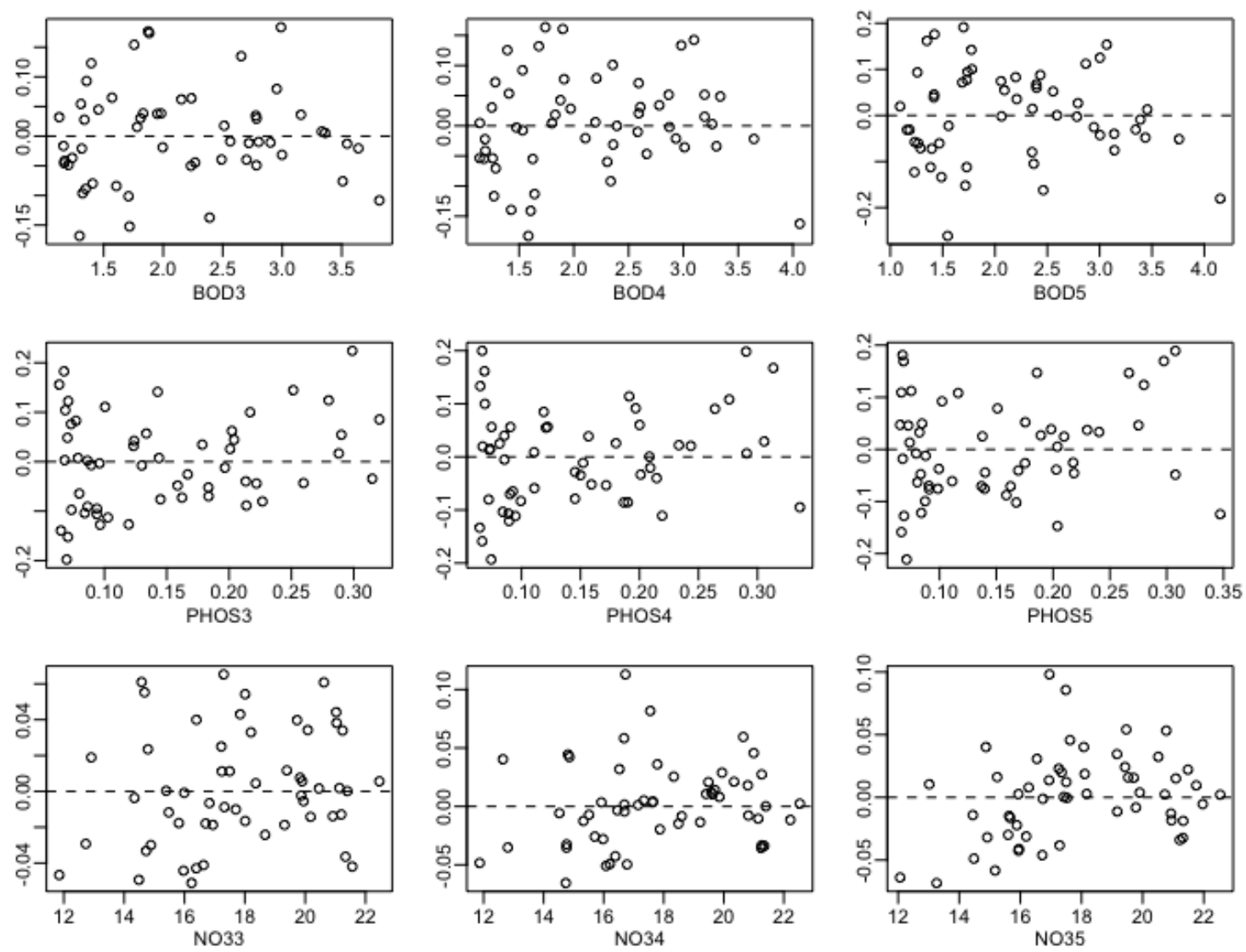

\section{Figure A2}

830 Residuals vs. fitted values in gamma log models
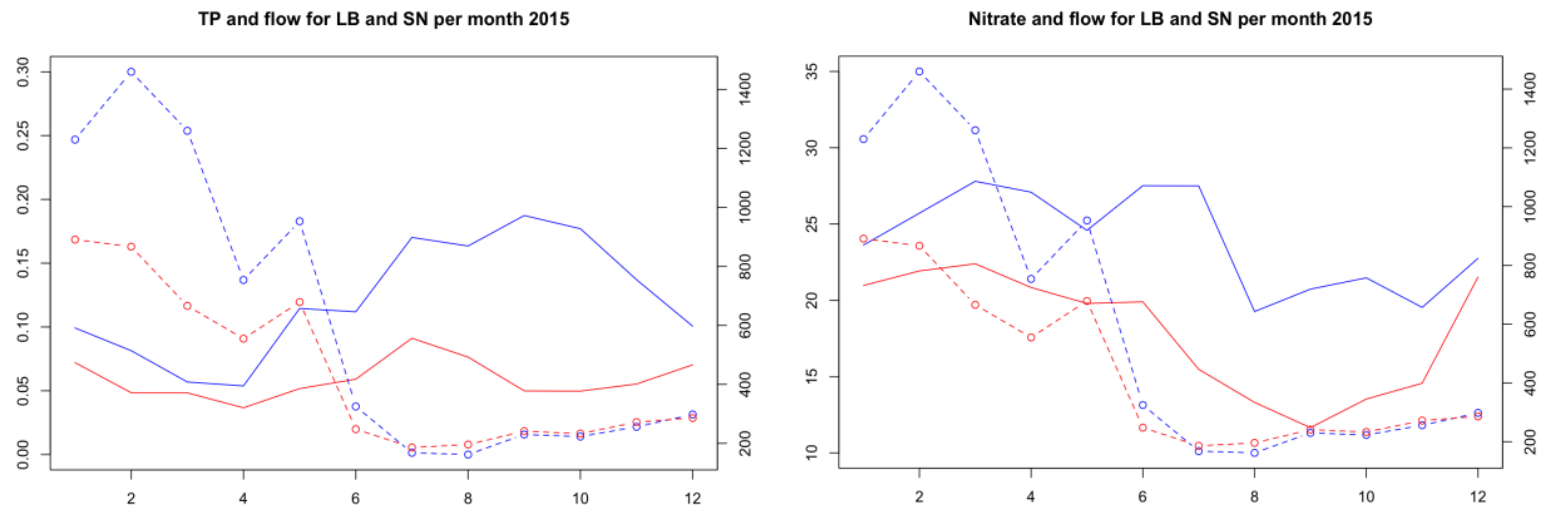

Monthly trends of flow and concentrations of TP (left panel) and $\mathrm{NO}_{3}$ (right panel) in 2015. Data for LB in blue, for SN in red. The full line represents the concentration (in $\mathrm{mg} \mathrm{L}^{-1}$ ), the dashed line represents the flow (in $\mathrm{m}^{3} \mathrm{~s}^{-1}$ ). 
Table A1

840 Pearson correlation coefficients between NO3 and TP concentration and flow on monthly data for LB and SN covering years 8412010 to 2018

\begin{tabular}{llll} 
& Flow & NO3 concentration & TP concentration \\
\hline Flow & 1.000 & $0.471^{* * *}$ & $-0.460^{* * *}$ \\
NO3 concentration & & 1.000 & $-0.431^{* * *}$ \\
TP concentration & & 1.000 \\
$\quad{ }^{*} p<0.1 ;{ }^{* *} p<0.05 ;{ }^{* * *} p<0.01$ & &
\end{tabular}

842

Notes: $\quad{ }^{*} p<0.1 ;^{* *} p<0.05 ;{ }^{* * *} p<0.01$ 